\title{
Electrochemical and Tribological and Mechanical Performances Coatings Multilayer Type NbC / CrN
}

\author{
W. Aperador ${ }^{*}$, J. Duque, E. Delgado \\ School of Engineering, Universidad Militar Nueva Granada, Bogotá-Colombia \\ "E-mail: g.ing.materiales@gmail.com
}

doi: $10.20964 / 2016.07 .79$

Received: 27 April 2016 / Accepted: 17 May 2016 / Published: 4 June 2016

\begin{abstract}
Niobium nitride / Chromium nitride multilayer coatings deposited by unbalanced magnetron sputtering system, with two cathodes in alternate positions $(\mathrm{Nb} / \mathrm{Cr})$. Four multilayer $\mathrm{NbN} / \mathrm{CrN}$ coatings were produced with different periodicities $(1100 \mathrm{~nm}, 440 \mathrm{~nm}, 220 \mathrm{~nm}$ and $110 \mathrm{~nm}$ ) with total thickness from $2.2 \mu \mathrm{m}$ in all cases. Mechanical and tribological characterization was conducted by microhardness measurements and tests pin-on-disk; according to ASTM G99-05 standard to $25^{\circ} \mathrm{C}$, in order to evaluate and compare the wear resistance of the multilayers study, increased hardness and reduced coefficient of friction with the content of more layers from low to high periodicity was determined, indicating a potential better performance of the lower periodicity multilayer coating systems in service. Also is conducted the study of the electrochemical behavior coatings analyzed under a corrosive environment by Tafel polarization curves, determining the protection generated by the thin films.
\end{abstract}

Keywords: Multilayer, Niobium nitride, Chromium nitride, wear, corrosion.

\section{$\underline{\text { FULL TEXT }}$}

(C) 2016 The Authors. Published by ESG (www.electrochemsci.org). This article is an open access article distributed under the terms and conditions of the Creative Commons Attribution license (http://creativecommons.org/licenses/by/4.0/). 